\title{
Victimization of the mentally ill
}

\section{Vitimização de doentes mentais}

\author{
Alan de Freitas Passos ${ }^{1}$, Bárbara Perdigão Stumpf ${ }^{1}$, Fábio Lopes Rocha ${ }^{1}$ \\ 1 Instituto de Previdência dos Servidores do Estado de Minas Gerais (IPSEMG). \\ Institution where the study was elaborated: Instituto de Previdência dos Servidores do Estado de Minas Gerais (IPSEMG).
}

Received: 1/18/2013 - Accepted: 7/25/2013

\begin{abstract}
Background: Individuals with serious mental illnesses compose a group particularly vulnerable to victimization. This major susceptibility to violent crimes is due to the impairment of their cognitive functions and to the living conditions of these individuals. Objectives: This paper aimed to perform a systematic review of the literature about the occurrence and factors associated with victimization in this population, in addition to evaluate the national literature about the subject. Methods: Publications that assessed the prevalence of victimization in individuals with serious mental illness were analyzed. Medline (1966 to February 2013) and Lilacs (1982 to February 2013) databases were searched. Separate searches were conducted for the keywords "mental illness", "psychiatric disorder(s)", "mental disorder(s)", "schizophrenia", "psychosis", "psychotic", "depression", "bipolar", combined with each of the following keywords: "victimization", "victimisation", "sexual abuse", "physical abuse". Results: Twenty papers were found. There were no publications on the topic in national and Latin-American literature. Although they differ in methodology, in the concept of victimization and in sociodemographic and clinical variables, the studies showed that patients with serious mental disorders present higher risk of victimization when compared to the general population. The main factors associated with victimization were: substance use, young age, severe symptomatology, recent history of violence perpetration, criminal history, male gender, and homelessness. Discussion: Individuals with serious mental disorders show high rates of victimization. The subject deserves further studies in our area.
\end{abstract}

Passos AF, et al. / Rev Psiq Clín. 2013;40(5):191-6

Keywords: Mentally ill persons, mental disorders, victimization, crime victims.

\section{Resumo}

Contexto: Os indivíduos portadores de doenças mentais graves constituem um grupo particularmente vulnerável à vitimização. Essa maior suscetibilidade a crimes violentos deve-se ao comprometimento de suas funções cognitivas e às condições de vida desses indivíduos. Objetivos: Este trabalho teve como objetivos realizar revisão sistemática sobre a ocorrência e fatores associados à vitimização nessa população, além de avaliar a literatura nacional acerca do tema. Métodos: Foram analisadas publicações que avaliaram a prevalência de vitimização em portadores de doença mental grave. Foram consultadas as bases de dados Medline (1966 a fevereiro de 2013) e Lilacs (1982 a fevereiro de 2013). Pesquisas separadas foram realizadas para os termos descritores: "mental illness", "psychiatric disorder(s)", "mental disorder(s)", "schizophrenia", "psychosis", "psychotic", "depression", "bipolar", combinados com os seguintes termos: "victimization", "victimisation", "sexual abuse", "physical abuse". Resultados: Foram encontrados 20 estudos. Não houve publicações sobre o assunto na literatura nacional e latino-americana. Apesar de apresentarem diferenças na metodologia, no conceito de vitimização e nas variáveis sociodemográficas e clínicas, os estudos evidenciaram que os pacientes com transtornos mentais graves apresentam maior risco de vitimização se comparados à população em geral. Os principais fatores associados à vitimização foram uso de substâncias, idade jovem, sintomatologia grave, história recente de perpetração de violência, passado criminal, sexo masculino e ausência de moradia fixa. Conclusão: Os portadores de transtorno mental grave apresentam elevadas taxas de vitimização. O tema merece ser estudado em nosso meio.

Passos AF, et al. / Rev Psiq Clín. 2013;40(5):191-6

Palavras-chave: Pessoas mentalmente doentes, transtornos mentais, vitimização, vítimas de crimes.

\section{Introduction}

Individuals with severe mental illness are particularly susceptible to violent crimes such as assault, rape, mugging, robbery and murder ${ }^{1-4}$. The term "severe mental illness" refers to a subset of psychiatric disorders - psychotic disorders and major affective disorders - which are characterized by severe and persistent cognitive, behavioral and emotional symptoms that reduce daily functioning 5 . Opposite to the stereotype of dangerousness associated to those with serious mental illness, these individuals present higher rates of victimization than of perpetrating violent acts, i.e., they are more often victims than perpetrators $2,5,6$.

One of the reasons behind the greater vulnerability of those with severe mental illness to violent crimes is the significant impairment of their cognitive functions. Patients present impaired reality testing, disorganized thought processes, greater impulsivity and poor planning and problem solving ${ }^{6-8}$. Furthermore, this group presents a high prevalence of factors known for being associated with victimization such as, for example, poverty, social isolation, unemployment, substance abuse, conflicted relationships and lack of secure environments ${ }^{6-8}$.

Among patients with mental disorders, victimization may lead to serious consequences such as the exacerbation of pre-existing psychiatric symptoms, increase in the usage of mental health services, including psychiatric hospitalization, and substantially diminish quality of life. Moreover, victimization may increase the likelihood of revictimization and perpetration of violence in this population'.

"Victimization" is defined as the act of being a victim of any aggressive behavior 9 . As the term is imprecise, most authors distinguish between violent and non-violent victimization. The concept of violent victimization includes being victim of violent acts such as: being murdered, suffering aggravated assault, being hurt by someone 
with a firearm, knife or other object, and being forced to have sexual relations against one's will. By non-violent victimization, it is inferred: being a victim of any aggressive behavior such as being pushed, grabbed, kicked, beaten, bitten, strangled, threatened of sexual abuse, threatened by someone with a firearm, amongst others 9 .

The last systematic review concerning the occurrence and factors associated to victimization of individuals with serious mental disorders covered publications up to $2007^{8}$ and does not include Latin-American literature. This review aims to include publications of the past five years and, particularly, to evaluate researches carried out in Brazil regarding the subject.

\section{Methods}

This study is a systematic review of literature. Publications evaluating the prevalence of victimization in individuals with serious mental disorders were analyzed. Medline (period from January 1966 to February 2013) and Latin-American and Caribbean Center on Health Sciences Information - Lilacs (1982 to February 2013) databases were searched. The search strategy was similar to that of Maniglio (2009)8. Separate searches were conducted for the keywords: mental illness, psychiatric disorder(s), mental disorder(s), schizophrenia, psychosis, psychotic, depression, bipolar, combined with each of the following keywords: victimization, victimization, sexual abuse, physical abuse. Publications in both Portuguese and English were evaluated. Previous systematic reviews and reference lists from retrieved papers were also consulted.

Studies were included if they met the following criteria: (a) appeared in peer-reviewed journals; (b) were published in full; (c) were not reviews, perspectives, dissertation papers, conference proceedings, editorials, case reports, case-series, letters, commentaries, books and book chapters; (d) sampled individuals who were 18 years of age or older; (e) sampled subjects with a major mental disorder (for example, schizophrenia, other psychotic disorders, major depression or bipolar disorder); (f) included both male and female individuals; (g) did not limit their investigation to special populations (for example, homeless people, drug users) and/or specific types of crime (for example, domestic violence); (h) explicitly reported rates of prevalence and/or incidence over a definite period (for example, 1 - year prevalence); and (i) investigated victimization happened after the onset of mental disorder.

The initial search results were evaluated by researchers independently through the screening of each abstract. In case of incomplete information in the abstract, the full text was assessed. After this first screening, all selected studies were reevaluated. Occasional disagreements on the eligibility of studies or data collected were decided during meetings among the authors. Risk of bias assessment was evaluated according to recommendations of the Cochrane Collaboration Handbook, taking into account the following criteria: sequence generation and allocation concealment (selection bias); blinding of participants and personnel (performance bias); blinding of outcome assessment (detection bias); incomplete outcome data (attrition bias); selecting outcome reporting (reporting bias); and other sources of bias $^{10}$. The studies were classified as having low, unclear/moderate or high risk of bias.

\section{Results}

Out of the 162.117 articles retrieved through the search strategy, 131.315 were duplicated and 30.754 were excluded because they failed to meet the inclusion criteria. Sixty articles were read in full and twenty were included (Figure 1).

\section{Description of studies}

Twenty studies were included in this review (Table 1): Lehman and Linn, 1984; Brunette and Drake, 1997; Hiday et al., 1999; Brekke et al., 2001; Goodman et al., 2001; Silver, 2002; Walsh et al., 2003; Chapple et al., 2004; Honkonen et al., 2004; Fitzgerald et al., 2005; Teplin et al., 2005; Silver et al., 2005; White et al., 2006; Pandiani et al., 2007; Hodgins et al., 2007; Schomerus et al., 2008; Ascher-Svanum et al., 2010; Sturup et al., 2011; Katsikidou et al., 2012; e Bengtsson-Tops and Ehliasson, 20126,7,9,11-27.

All included studies were published between 1984 and 2012. Of these studies, ten were conducted in the United States $6,7,11-15,21,22,24$, two in England9,16, two in Australia ${ }^{17,19}$, two in Sweden ${ }^{25,27}$, one in Finland ${ }^{18}$, one in New Zealand ${ }^{20}$, one in Greece ${ }^{26}$ and one was a multicentric study ${ }^{23}$. The total sample size was of 13.997 individuals, of whom $53,5 \%(7.490 / 13.997)$ were male. The number of participants in each study varied between 172 and 2610. No studies involving Brazilian populations were found.

The individuals included in the studies suffered from serious mental disorders. Only six studies excluded the homeless $6,11,18,19,23,26$. All studies included alcohol and/or illicit drugs users. Just one study investigated the prevalence of victimization through database analysis $^{22}$. In all others, victimization was assessed during a clinical interview and measured by the participant's responses to direct questions. The incidence of victimization was investigated in two studies ${ }^{6,13}$. Ten studies assessed if the patients had perpetrated violence ${ }^{9,11-13,15,16,18-20,22}$ and nine assessed if the individuals had been arrested ${ }^{11-13,15,17,19,21,23,24}$. In eleven studies, prevalence and/or incidence rates were compared with the official statistics of each country $y^{6,7,9,13,14,16-18,21,22,25}$.

Regarding the methodological quality of the included studies, all of them had high risk of bias.

\section{Prevalence and incidence of victimization}

Prevalence rates of victimization in psychiatric patients ranged from $4,3 \%$ to $59 \%$. This variation concerns methodological factors; these include the population studied (for example, inpatients, patients residing in the community, type of diagnosis, amongst other things), type of victimization (violent or non-violent), the period considered (prevalence in 12 months, 36 months, amongst others) and the form of collecting data (through interviews or databases). In community studies, in urban areas, prevalence rates ranged from $4,3 \%$ to $42,6 \%{ }^{11-13,15,16,19-21,27}$. Results were similar when considering only rural areas $7,18,22-24,26$.

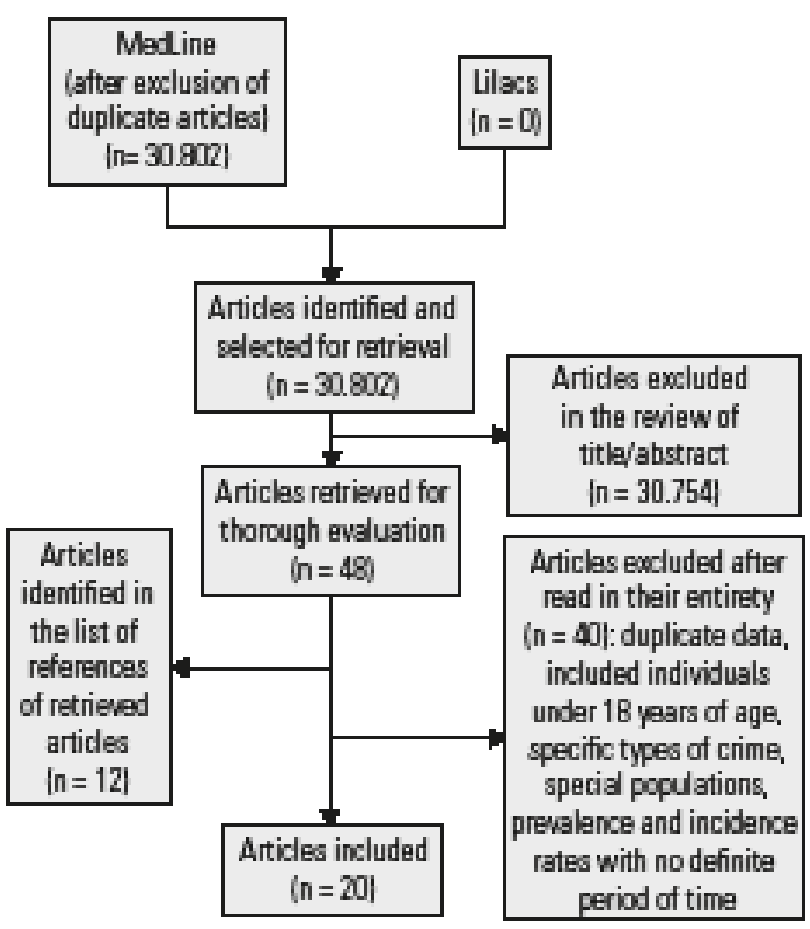

Figure 1. Summary of the study selection process. 
Table 1. Prevalence of victimization in individuals with serious mental disorders

\begin{tabular}{|c|c|c|c|c|c|c|c|}
\hline Study & Setting & $\mathrm{n}$ & $\begin{array}{c}\text { Standardized } \\
\text { Diagnostic } \\
\text { Instrument } \\
\end{array}$ & Diagnosis & $\begin{array}{c}\text { Period } \\
\text { (months) }\end{array}$ & $\begin{array}{l}\text { Prevalence rates of } \\
\text { victimization }\end{array}$ & $\begin{array}{l}\text { Risk factors } \\
\text { OR (95\% } 19 \mathrm{CI})\end{array}$ \\
\hline $\begin{array}{l}\text { 1. Lehman } \\
\text { and Linn } \\
\text { (1984) }\end{array}$ & USA & 278 & No & $\begin{array}{c}\text { Schizophrenia (63\%) } \\
\text { Alcoholism (11\%) } \\
\text { Organic mental disorder (10\%) } \\
\text { Affective disorder (9\%) } \\
\text { Personality disorder }(9 \%) \\
\text { Substance use disorder }(4 \%)\end{array}$ & 12 & $\begin{array}{l}33 \% \text { general } \\
8 \% \text { violent } \\
15 \% \text { non-violent } \\
10 \% \text { both }\end{array}$ & $N A^{b}$ \\
\hline $\begin{array}{l}\text { 2. Brunette } \\
\text { and Drake } \\
\text { (1997) }\end{array}$ & USA & 172 & SCIDc & $\begin{array}{c}\text { Schizophrenia }(69 \%) \\
\text { Schizoaffective }(31 \%) \\
\text { Antisocial personality disorder } \\
(20 \%) \\
\text { Substance use disorder }(100 \%)\end{array}$ & 12 & $\begin{array}{c}19,8 \% \text { violent } \\
20,3 \% \text { non-violent }\end{array}$ & $N A^{b}$ \\
\hline $\begin{array}{l}\text { 3. Hiday et al. } \\
\text { (1999) }\end{array}$ & USA & 331 & No & $\begin{array}{c}\text { Schizophrenia/Schizoaffective } \\
(55,9 \%) \\
\text { Affective psychosis }(31,1 \%) \\
\text { Other psychotic disorders }(13 \%) \\
\text { Personality disorder }(12,4 \%) \\
\text { Substance use disorder }(21,1 \%)\end{array}$ & 4 & $\begin{array}{c}8,2 \% \text { violent } \\
22,4 \% \text { non-violent }\end{array}$ & $\begin{array}{c}\text { Education: } 1,15(1,0-1,3) \\
\text { Substance use: 1,93 (1,12-3,39) } \\
\text { Homelessness: } 3,37(1,78-6,43)\end{array}$ \\
\hline \begin{tabular}{|l|} 
4. Brekke et \\
al. (2001) \\
\end{tabular} & USA & 172 & SADSd & Schizophrenia Schizoaffective & 36 & $\begin{array}{l}34 \% \text { violent } \\
38 \% \text { general }\end{array}$ & $\begin{array}{c}\text { Severe symptoms: } 1,04(1,02-1,07) \\
\text { Substance use: } 1,28(1,02-1,60)\end{array}$ \\
\hline $\begin{array}{l}\text { 5. Goodman } \\
\text { et al. (2001) }\end{array}$ & USA & 782 & SCIDc & $\begin{array}{c}\text { Schizophrenia }(67,9 \%) \\
\text { BADe }(18,1 \%) \\
\text { Major depressive disorder }(9,9 \%) \\
\text { Substance use disorder }(35,9 \%) \\
\text { Others }(3,3 \%)\end{array}$ & 12 & $\begin{array}{l}\text { violent: } \\
33,4 \% \text { female } \\
36,7 \% \text { male }\end{array}$ & $\begin{array}{c}\text { Homelessness: } 1,74 \\
\text { Alcoholism: } 1,63 \\
\text { Substance abuse: } 2,05 \\
\text { Hospitalization: } 2,25 \\
\text { Age at 1st hospitalization: } 0,96 \\
\text { Child sexual abuse: } 1,50 \\
\text { Child physical abuse: } 2,10\end{array}$ \\
\hline $\begin{array}{l}\text { 6. Silver } \\
\text { (2002) }\end{array}$ & USA & $\begin{array}{l}270 \text { patients } \\
477 \text { controlsf }\end{array}$ & No & $\begin{array}{c}\text { Schizophrenia Depression } \\
\text { Mania } \\
\text { Psychosis } \\
\text { Delusion } \\
\text { Substance abuse disorder } \\
\text { Personality disorder }\end{array}$ & 2,5 & $\begin{array}{c}\text { violent: } \\
15,2 \% \text { patients } \\
6,9 \% \text { controls }^{f}\end{array}$ & $\begin{array}{c}\text { Perpetration of violence: } 4,04 \\
\text { Dangerous neighborhood: } 1,37 \\
\text { Conflicted social relationships: } 1,51\end{array}$ \\
\hline $\begin{array}{l}\text { 7. Walsh et } \\
\text { al. (2003) }\end{array}$ & England & 691 & $\mathrm{RDCg}$ & $\begin{array}{c}\text { Schizoaffective }(48,7 \%) \\
\text { Schizophrenia }(38,3 \%) \\
\text { Affective psychosis }(6,9 \%) \\
\text { Other psychosis }(5,9 \%) \\
\text { Personality disorder }(32,7 \%)\end{array}$ & 12 & $16 \%$ violent & $\begin{array}{c}\text { Homelessness: } 2,67(1,23-5,77) \\
\text { Substance abuse: } 3,81(1,87-7,77) \\
\text { Violence perpetration: } 2,08 \\
(1,18-3,43) \\
\text { Severe symptoms: } 1,02(1,00-1,04) \\
\text { Personality disorder: } 1,93(1,20-3,10)\end{array}$ \\
\hline $\begin{array}{l}\text { 8. Chapple et } \\
\text { al. (2004) }\end{array}$ & Australia & 962 & $\mathrm{DIPh}$ & $\begin{array}{c}\text { Schizophrenia }(58,9 \%) \\
\text { BADe }(19,1 \%) \\
\text { Psychotic depression }(10,9 \%)\end{array}$ & 12 & $17,9 \%$ violent & $\begin{array}{c}\text { Female gender: } 1,55(1,05-2,29) \\
\text { Homelessness: } 2,51 \text { (1,57-4,02) } \\
\text { Lifetime substance abuse: } \\
\text { 1,49 (1,03-2,17) } \\
\text { History of arrest: } 2,74(1,69-4,45) \\
\text { Poor social and occupational } \\
\text { functioning: } 1,90(1,24-2,90) \\
\text { Psychic disorganization: } 2,36(1,06- \\
\text { 5,25) }\end{array}$ \\
\hline $\begin{array}{l}\text { 9. Honkonen } \\
\text { et al. (2004) }\end{array}$ & Finland & 670 & No & Schizophrenia (100\%) & 36 & $5,6 \%$ violent & $\begin{array}{c}\text { Poverty: } 3,58(1,70-7,54) \\
\text { Alcohol abuse: } 4,12(1,84-9,25) \\
\text { Perpetration of a violent crime: } \\
13,71(4,58-41,05) \\
\text { Perpetration of a non-violent crime: } \\
8,51(1,51-47,96)\end{array}$ \\
\hline $\begin{array}{l}\text { 10. Fitzgerald } \\
\text { et al. (2005) }\end{array}$ & Australia & 348 & No & $\begin{array}{c}\text { Schizophrenia }(76,3 \%) \\
\text { Schizoaffective }(11,3 \%) \\
\text { Schizophreniform }(12,4 \%) \\
\end{array}$ & 1 & \begin{tabular}{c|}
$13,2 \%$ general \\
$4,3 \%$ violent \\
$11,2 \%$ non-violent \\
\end{tabular} & Lack of daily activity: $1,4(1,01-1,86)$ \\
\hline $\begin{array}{l}\text { 11. Teplin et } \\
\text { al. (2005) }\end{array}$ & USA & 936 & CIDli & $\begin{array}{c}\text { Psychotic disorder } \\
\text { Major affective disorder }\end{array}$ & 12 & $\begin{array}{c}25,3 \% \text { violent } \\
21,2 \% \text { non-violent }\end{array}$ & $N A^{b}$ \\
\hline $\begin{array}{l}\text { 12. Silver et } \\
\text { al. (2005) }\end{array}$ & $\begin{array}{c}\text { New } \\
\text { Zealand }\end{array}$ & $\begin{array}{l}382 \text { patients } \\
562 \text { controls }\end{array}$ & DISi & $\begin{array}{c}\text { Depressive disorder }(43,9 \%) \\
\text { Anxiety disorder }(50,5 \%) \\
\text { Schizophreniform }(9,9 \%) \\
\text { Alcoholism }(24,1 \%) \\
\text { Cannabis dependence }(23,8 \%)\end{array}$ & 12 & $\begin{array}{c}\text { violent: } \\
\text { 42,6\% cases } \\
\text { 21,3\% controls } \\
\text { non-violent: } \\
\text { 34,0\% cases } \\
\text { 15,6\% controls }\end{array}$ & $N A^{b}$ \\
\hline
\end{tabular}




\begin{tabular}{|c|c|c|c|c|c|c|c|}
\hline Study & Setting & $\mathrm{n}$ & \begin{tabular}{|c|} 
Standardized \\
Diagnostic \\
Instrument \\
\end{tabular} & Diagnosis & $\begin{array}{l}\text { Period } \\
\text { (months) }\end{array}$ & $\begin{array}{l}\text { Prevalence rates of } \\
\text { victimizationa }\end{array}$ & $\begin{array}{l}\text { Risk factors } \\
\text { OR (95\% } \mathrm{CI})\end{array}$ \\
\hline $\begin{array}{l}\text { 13. White et } \\
\text { al. (2006) }\end{array}$ & USA & 308 & No & $\begin{array}{c}\text { Depression }(50 \%) \\
\text { Psychotic disorder }(33,4 \%) \\
\text { BADe }(11,4 \%) \\
\text { Others }(5,2 \%)\end{array}$ & 6 & $\begin{array}{l}25,6 \% \\
\text { violent }\end{array}$ & $\begin{array}{l}\text { Female gender: } 2,02(1,2-3,5) \\
\text { Homelessness: } 2,10(1,2-3,8)\end{array}$ \\
\hline $\begin{array}{l}\text { 14. Hodgins et } \\
\text { al. (2007) }\end{array}$ & England & 205 & SCIDc & $\begin{array}{c}\text { Schizophrenia }(64,9 \%) \\
\text { Schizoaffective }(8,8 \%) \\
\text { BADe }(19,5 \%) \\
\text { Depression }(4,4 \%) \\
\text { Others }(3,9 \%)\end{array}$ & 6 & $\begin{array}{c}\text { general: } \\
57 \% \text { male } \\
48 \% \text { female }\end{array}$ & $\begin{array}{l}\text { Recent aggressive behavior: 6,57 } \\
(3,51-12,28)\end{array}$ \\
\hline $\begin{array}{l}\text { 15. Pandiani } \\
\text { et al. (2007) }\end{array}$ & USA & 2,610 & No & Serious mental disorder & 12 & $7,1 \%$ general & $N A^{b}$ \\
\hline $\begin{array}{l}16 . \\
\text { Schomerus et } \\
\text { al. (2008) }\end{array}$ & $\begin{array}{l}\text { England } \\
\text { France } \\
\text { Germany }\end{array}$ & 1,208 & SCANk & Schizophrenia (100\%) & 30 & $\begin{array}{c}10 \% \text { violent } \\
19 \% \text { non-violent }\end{array}$ & $N A^{b}$ \\
\hline $\begin{array}{l}\text { 17. Ascher- } \\
\text { Svanum et al. } \\
\text { (2010) }\end{array}$ & USA & 609 & BPRSI & $\begin{array}{l}\text { Schizophrenia Schizoaffective } \\
\text { Schizophreniform } \\
\text { Substance use disorder (52\%) }\end{array}$ & 24 & $30,7 \%$ general & $N A^{b}$ \\
\hline $\begin{array}{l}\text { 18. Sturup et } \\
\text { al. (2011) }\end{array}$ & Sweden & $\begin{array}{c}390 \text { patients } \\
1,170 \text { controls }\end{array}$ & No & $\begin{array}{c}\text { Mood disorder (32\%) } \\
\text { Psychotic disorder (20\%) } \\
\text { Personality disorder (14\%) } \\
\text { Substance use disorder (6\%) } \\
\text { Others (28\%) }\end{array}$ & 12 & $\begin{array}{c}\text { violent: } \\
10,2 \% \text { patients } \\
\text { 1,3\% controls } \\
\text { non-violent: } \\
\text { 14,5\% patients } \\
2,9 \% \text { controls } \\
\end{array}$ & $N A^{b}$ \\
\hline $\begin{array}{l}\text { 19. Katsikidou } \\
\text { et al. (2012) }\end{array}$ & Greece & $\begin{array}{l}150 \text { patients } \\
150 \text { controls }\end{array}$ & No & $\begin{array}{c}\text { Schizophrenia Schizoaffective } \\
\text { BADe }\end{array}$ & 12 & $\begin{array}{c}\text { general: } \\
59,3 \% \text { patients } \\
46,0 \% \text { controls }\end{array}$ & $\begin{array}{c}\text { Civil / professional servant: } 3,09 \\
(1,12-8,50)\end{array}$ \\
\hline $\begin{array}{l}\text { 20. Bengtsson- } \\
\text { Tops and } \\
\text { Ehliasson } \\
\text { (2012) }\end{array}$ & Sweden & 174 patients & No & Psychotic disorder & 12 & $33 \%$ general & $N A^{b}$ \\
\hline
\end{tabular}

a Prevalence of victimization rates: calculation is done by dividing the number or victimized people by the total of people included in the study; b NA: not available; c SCID: Structured Clinical Interview for DSM; ‘ dSADS: Schedule for Affective Disorders and Schizophrenia; e BAD: bipolar affective disorder; ${ }^{\circ}$ Controls: individuals with no mental disorder; 9 RDC: Research Diagnostic Criteria; hDIP: Diagnostic Interview for Psychosis; i CIDI: Composite International Diagnostic Interview; i DIS: Diagnostic Interview Scale; kSCAN: Schedules for Clinical Assessment in Neuropsychiatry interview; 'BPRS: Brief Psychiatric Rating Scale.

In some specific groups, prevalence rates were higher, such as, for example, in schizophrenic patients with comorbid substance dependence $(40,1 \%, 19,8 \%$ of which being of violent crimes and $20,3 \%$ of non-violent crimes) ${ }^{12}$.

In studies which included in and outpatients, estimates of violent victimization ranged from $17,9 \%$ to $36,7 \% 6,14,17$. Teplin et al., in Chicago, reported that the prevalence of violent victimization was 11,8 times higher than the one found in the National Crime Victimization Survey (NCVS) 28 .

In board-and-care homes, throughout the period of twelve months, the victimization rate found was of $33 \%^{11}$. In hospitalized patients, on the other hand, prevalence of victimization ranged from $20 \%{ }^{25}$ to $48 \%$ in females and was of $57 \%$ in male individuals 9 . In the study carried out by Sturup et al., developed in Stockholm, prevalence in hospitalized individuals was six times higher than the one found in the general population ${ }^{25}$.

The annual incidence of victimization of schizophrenic patients in the community ranged from $12,7 \%$ to $17,7 \%^{13}$. In a study which included psychiatric in and outpatients, the incidence of violent crimes was of 168,2 per 1000 people/year, a number four times higher than that found in the NCVS' 6 .

\section{Factors associated with victimization}

In community studies, factors most commonly associated were

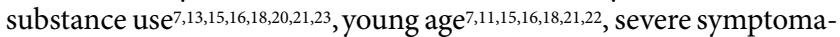
tology ${ }^{13,16,19,23,26}$, recent history of perpetration of violence ${ }^{15,16,18,19,22}$, engagement in criminal activity ${ }^{11,16,19,23}$, male gender ${ }^{11,15,16,18}$ and homelessness ${ }^{14,17}$.
With regard to studies which included in and outpatients, the factors most commonly associated were substance use ${ }^{14,17}$, young age $^{6,14}$ and homelessness ${ }^{14,17}$. Regarding hospitalized patients, the factor most commonly associated was recent aggressive behavior ${ }^{9}$.

\section{Discussion}

Twenty studies addressing the prevalence of victimization among severely mentally ill persons were included in this review. Only four studies were added to the international literature in the past five years. No studies or even reviews on the subject were found in Latin-American and national literature. Despite presenting differences concerning methodology, the concept of victimization and clinical and sociodemographic variables, the studies showed that patients with serious mental disorders present higher risk of victimization when compared to the general population.

In psychiatric patients, prevalence rates of victimization ranged from $4,3 \%$ to $59 \%$. The great variation of rates is due to methodological factors previously mentioned. The main factors associated with victimization were substance use, young age, severe symptomatology, recent history of perpetration of violence, engagement in criminal activity, male gender and homelessness. As it is true for the general population, mentally ill individuals with comorbid substance disorders are more victimized than others. It is possible that substance use put these persons into dangerous places and situations ${ }^{7}$. Drug use may also lead to prostitution, which is associated with sexual aggression in mentally ill women ${ }^{14}$. Furthermore, also similar to what happens to the general population, younger people also presented higher rates of victimization. 
It is also known that several individuals with serious mental disorders have low socioeconomic conditions and live in areas with high crime rates, which leads to greater chances of victimization? ${ }^{7}$. Individuals with mental disorders who engage in criminal activities have higher probability of being victimized than others, due to cognitive impairment ${ }^{6,7,11}$. On the other hand, victimized individuals feel threatened and unsafe and, thus, may start to commit crimes ${ }^{16}$.

As for gender, mentally ill women presented greater chance of suffering sexual abuse and men of suffering physical abuse. Prior research both in general community samples and in severe mental illness samples showed that, for vulnerable individuals, physical and sexual victimization occur repeatedly across the lifespan ${ }^{14}$.

Individuals with severe psychiatric disorders who live on the streets presented high rates of victimization. Studies conducted in the United States and Australia showed that this number has been rising due to the discharging of these patients ${ }^{6,29}$. It is hard to assess if they went to the streets before or after being victimized. Homeless patients generally present more severe symptomatology, which leads them to getting involved in dangerous situations. However, it is also possible they opted for living in the streets after being victims of domestic violence $^{14}$. The lack of studies or reviews on the subject in Brazil is conspicuous. Due to reasons that will not be discussed in this paper, the scientific community in our country has not been awakened to the importance of the subject. There are studies involving homeless population and mental disorders ${ }^{30-32}$. Nevertheless, the subject of victimization was not approached in these studies. Aggressions suffered by the homeless are mentioned in lay literature ${ }^{33,34}$, but without approaching any aspects of mental disorders.

Generally, the evaluated studies presented limitations. One of these is that, in virtually all studies, we sampled individuals with serious mental disorders in treatment $6,7,9,11-19,21,24-27$. Therefore, the results cannot be generalized to all with severe psychiatric disorders. Another limitation is the fact that many studies provided little information about the specific type of crime and the context in which it occurred 8 . In the study carried out by Bengtsson-Tops and Ehliasson, for example, more than half of the patients victimized during the previous year reported no involvement of alcohol or drugs in the victimization situation for either perpetrators or patients ${ }^{27}$. Another issue regards the collection of victimization data. It is known that self-reports limit validity and reliability of data. On the other hand, as many victims do not report to police, official prevalence rates of victimization are underestimated $6-8,11,14,19,25$. A possible explanation is that mentally disordered victims fear their allegations will not be taken seriously ${ }^{20}$. One other reason could be fear of retaliation by their tormentors ${ }^{35}$. In a Swedish study, for example, $45 \%$ of perpetrators of violence were acquaintances of the victims (friends, neighbors, members of user organizations $)^{27}$.

This subject requires further research. As cross-sectional studies do not permit inferences of cause and effect, longitudinal studies to identify risk factors are necessary. Moreover, we need studies which include special populations and community samples of psychiatric patients; studies which include a non-psychiatric sample as control group, studies that specify the types of crimes and the contexts in which such crimes occur, studies which use standardized instruments to assess victimization and studies which include the mentally ill living in other cultures, specially in developing countries ${ }^{6,8,11}$. A Taiwanese study, for example, in contrast with western studies, showed that patients with major affective disorders present higher risk of victimization than schizophrenic individuals ${ }^{36}$.

Prevention and intervention programs must be implemented to reduce victimization of individuals with psychiatric disorders. Patients should be screened about victimization and subsequently monitored 29,36 . The occurrence of posttraumatic stress disorder as a result of victimization must be investigated once this may aggravate symptomatology and impair treatment outcomes ${ }^{6}$. Programs should target high-risk groups (e.g. homeless individuals, patients with more severe symptomatology, patients with comorbid substance dependence). Treating substance abuse among persons with severe mental illness will reduce personal vulnerability, reduce exposure to risk factors and may reduce the likelihood of revictimization 6 . It is equally important to build collaborative relationships between the mental health system and the criminal justice system. Police officers should be trained to manage mentally ill crime victims 6,36 . The improvement of living conditions, particularly in relation to housing and financial stability, could reduce the vulnerability of the mentally ill. It is also fundamental to raise awareness of the population concerning the negative stereotype of individuals with mental disorders ${ }^{6,37}$. It is important to highlight that the mental health sequelae of physical and sexual assault cannot be treated effectively until victimization itself stops and the victim can feel safe ${ }^{14}$.

\section{Conclusion}

Patients with severe mental disorders present higher risk of victimization when compared to the general population. The main factors associated with victimization in this group were substance use, young age, severe symptomatology, recent history of perpetration of violence, engagement in criminal activity, male gender and homelessness; data which corroborates previous reviews. Prevention and intervention programs must be implemented, and high-risk groups should be prioritized. Particularly in our country, the academic community should raise awareness of the subject and create lines of research.

\section{References}

1. Hiday VA, Swanson JW, Swartz MS, Borum R, Wagner HR. Victimization: a link between mental illness and violence? Int J Law Psychiatry. 2001;24:559-72.

2. Eisenberg L. Violence and the mentally ill. Arch Gen Psychiatry. 2005;62:825-26.

3. Friedman RA. Violence and mental illness - how strong is the link? N Engl J Med. 2006;355(20):2064-6.

4. Elbogen EB, Johnson SC. The intricate link between violence and mental disorder. Arch Gen Psychiatry. 2009;66(2):152-61.

5. Choe JY, Teplin L, Abram KM. Perpetration of violence, violent victimization and severe mental illness: balancing public health concerns. Psychiatr Serv. 2008;59:153-64.

6. Teplin LA, McClelland GM, Abram KM, Weiner DA. Crime victimization in adults with severe mental illness. Arch Gen Psychiatry. 2005;62:911-21.

7. Hiday VA, Swartz MS, Swanson JW, Borum R, Wagner HR. Criminal victimization of persons with severe mental illness. Psychiatr Serv. 1999;50:62-8.

8. Maniglio R. Severe mental illness and criminal victimization: a systematic review. Acta Psychiatr Scand. 2009;119:180-91.

9. Hodgins S, Alderton J, Cree A, Aboud A, Mak TM. Aggressive behavior, victimisation and crime among severely mentally ill patients requiring hospitalization. Br J Psychiatry. 2007;191:343-50.

10. Higgins JPT, Green S. Cochrane Handbook for Systematic Reviews of Interventions. Cochrane Book Series. Chichester: John Wiley \& Sons Ltd.; 2008.

11. Lehman AF, Linn LS. Crimes against discharged mental patients in board-and-care homes. Am J Psychiatry. 1984;141(2):271-4.

12. Brunette MF, Drake RE. Gender differences in patients with schizophrenia and substance abuse. Compr Psychiatry. 1997;38(2):109-16.

13. Brekke JS, Prindle C, Bae SW, Long JD. Risks for individuals with esquizophrenia who are living in the community. Psychiatr Serv. 2001;52(10):1358-66.

14. Goodman LA, Salyers MP, Mueser KT, Rosenberg SD, Swartz M, Essock $\mathrm{SM}$, et al. Recent victimization in women and men with severe mental illness: prevalence and correlates. J Trauma Stress. 2001;14:615-32.

15. Silver E. Mental disorder and violent victimization: the mediating role of involvement in conflicted social relationships. Criminology. 2002;40(1):191-212.

16. Walsh E, Moran P, Scott C, McKenzie K, Burns T, Creed F, et al. Prevalence of violent victimisation in severe mental illness. Br J Psychiatry. 2003;183:233-8.

17. Chapple B, Chant D, Nolan P, Cardy S, Whiteford H, Mcgrath J. Correlates of victimisation amongst people with psychosis. Soc Psychiatry Psychiatr Epidemiol. 2004;39:836-40. 
18. Honkonen T, Henriksson M, Koivisto AM, Stengard E, Salokangas RK. Violent victimization in schizophrenia. Soc Psychiatry Psychiatr Epidemiol. 2004;39:606-12.

19. Fitzgerald PB, de Castella AR, Filia KM, Filia SL, Benitez J, Kulkarni J. Victimization of patients with schizophrenia and related disorders. Aust N Z J Psychiatry. 2005;39:169-74.

20. Silver E, Arseneault L, Langley J, Caspi A, Moffitt TE. Mental disorder and violent victimization in a total birth cohort. Am J Public Health. 2005;95(11):2015-21.

21. White MC, Chafetz L, Collins-Bride G, Nickens J. History of arrest, incarceration and victimization in community-based severely mentally ill. J Community Health. 2006;31:123-35.

22. Pandiani JA, Banks SM, Carroll BB, Schlueter MR. Crime victims and criminal offenders among adults with serious mental illness. Psychiatr Serv. 2007;58:1483-5.

23. Schomerus G, Heider D, Angermeyer MC, Bebbington PE, Azorin JM, Brugha T, et al. Urban residence, victimhood and the appraisal of personal safety in people with schizophrenia: results from the European Schizophrenia Cohort (EuroSC). Psychol Med. 2008;38:591-7.

24. Ascher-Svanum H, Nyhuis AW, Faries DE, Ball DE, Kinon BJ. Involvement in the US criminal justice system and cost implications for persons treated for schizophrenia. BMC Psychiatry. 2010;10:11.

25. Sturup J, Sorman K, Lindqvist P, Kristiansson. Violent victimization of psychiatric patients: a Swedish case-control study. Soc Psychiat Epidemiol. 2011;46:29-34.

26. Katsikidou M, Samakouri M, Fotiadou M, Arvaniti A, Vorvolakos T, Xenitidis K, et al. Victimization of the severely mentally ill in Greece: the extend of the problem. Int J Soc Psychiatry. 2012. [Epub ahead of print].

27. Bengtsson-Tops A, Ehliasson K. Victimization in individuals suffering from psychosis: a Swedish cross-sectional study. J Psychiatr Ment Health Nurs. 2012;19:23-30.
28. US Department of Justice. National Crime Victimization Survey, 19921999. 9th ed. [database]. Ann Arbor, Mich: Inter-university Consortium for Political and Social Research; 2001.

29. Short TB, Thomas S, Luebbers S, Mullen P, Ogloff JR. A case-linkage study of crime victimization in schizophrenia-spectrum disorders over a period of deinstitutionalization. BMC Psychiatry. 2013;13:66.

30. Heckert U, Andrade L, Alves MJM, Martins C. Lifetime prevalence of mental disorders among homeless people in a southeast city in Brazil Eur Arch Psychiatry Clin Neurosci. 1999;249:150-5.

31. Lovisi GM, Mann AH, Coutinho E, Morgado AF. Mental illness in an adult sample admitted to public hostels in the Rio de Janeiro metropolitan area. Soc Psychiatry Psychiatr Epidemiol. 2003;38:493-8.

32. Botti NCL, Castro CG, Silva AK, Silva MF, Oliveira LC, Castro ACHOA, et al. Avaliação da ocorrência de transtornos mentais comuns entre a população de rua de Belo Horizonte. Barbarói. 2010;33:178-93.

33. Ministra quer que PF investigue morte de moradores de rua. Veja. 2013. Disponível em: <http://veja.abril.com.br/noticia/brasil/ministra-quer-que-federacao-investigue-homicidios-em-go $>$.

34. Peixoto P. Mortes de moradores de rua já somam 18 neste ano em $\mathrm{BH}$ Folha de São Paulo. 2013. Disponível em: <http://www1.folha.uol.com. br/cotidiano/2013/06/1293559-sob-para-18-o-numero-de-moradores-de-rua- mortos-neste-ano-em-bh.shtml>.

35. Serafim AP, Saffi F, Achá MFF, Barros DM. Dados demográficos, psicológicos e comportamentais de crianças e adolescentes vítimas de abuso sexual. Rev Psiq Clín. 2011;38(4):143-7.

36. Hsu CC, Sheu CJ, Liu SI, Sun YW, Wu SI, Lin Y. Crime victimization of persons with severe mental illness in Taiwan. Aust N Z J Psychiatr. 2009;43:460-6.

37. Guarniero FB, Bellinghini RH, Gattaz WF. O estigma da esquizofrenia na mídia: um levantamento de notícias publicadas em veículos brasileiros de grande circulação. Rev Psiq Clín. 2012;39(3):80-4. 